\title{
PROGRAM KEGIATAN PENDAMPINGAN BELAJAR ANAK PAUD DI RUMAH PADA MASA PANDEMI COVID-19 DENGAN MENGGUNAKAN STRATEGI PEMBELAJARAN BERBASIS INKUIRI
}

\author{
Elisabeth Tantiana Ngura'), Dek Ngurah Laba Laksana'), Yesi Herliani Bude ${ }^{3)}$, \\ Martina Mogi ${ }^{4}$
}

${ }^{1,3,4)}$ Pendidikan Anak Usia Dini, ${ }^{2}$ Pendidikan Guru Sekolah Dasar

1,2,3,4)Sekolah Tinggi Keguruan dan IImu Pendidikan Citra Bakti

1)elisabethngura@gmail.com, ${ }^{2)}$ Iaba.laksana@citrabakti.ac.id, ${ }^{3)}$ yessibude9@gmail.com,

\begin{abstract}
Histori artikel
Received:

14 Oktober 2020

Accepted:

29 November 2020

Published:

30 November 2020

Abstrak

Tujuan pengabdian ini adalah untuk 1). Untuk mendampingi anak belajar dari rumah di masa pandemi Covid-19, 2) Membina hubungan baik antara guru dan murid. 3) Guru dapat mengetahui kegiatan aktivitas anak dirumah secara langsung, 4) Memperlancar aktivitas belajar mengajar di tengah situasi Pandemi Covid-19, 5) Untuk membantu mahasiswa dalam mempersiapkan diri menghadapi dan memahami anak secara langsung. Penanganan Pendidikan Anak Usia Dini di lembaga (center base) tidak dapat dilepaskan dari penanganan PAUD di rumah (home base), keduanya saling terkait dan sejalan. Pembelajaran anak di lembaga yang hanya dapat mengisi anak sebesar $20 \%$ dimanfaatkan sebaik-baiknya oleh guru. Namun tidak menjadi berarti apabila saat anak berada dalam lingkungan keluarga tidak mendapat pendidikan yang tepat seperti yang dilaksanakan pada lembaga. Metode yang digunakan dalam melaksanakan kegiatan pengabdian ini adalah berbentuk Pembelajaran berbasis inkuiri dengan melakukan kunjungan rumah, sangat membantu guru dan murid dalam proses belajar mengajar. Hasil yang diperoleh dari pelaksanaan pengadian kepada masyarakat ini adalah Anak-anak tetap dapat belajar dari rumah melalui bimbingan guru dengan menggunakan strategi Pembelajaran Berbasis Inkuiri.
\end{abstract}

Kata-kata Kunci: anak, pandemi covid-19, pembelajaran inkuiri 
Abstract . The purpose of this service is to 1). To accompany children to learn from home during the Covid-19 pandemic, 2) Foster good relations between teachers and students. 3) Teachers can find out about children's activities at home directly, 4) Streamline teaching and learning activities in the midst of the PANDEMI COVID-19 situation, 5) To help students prepare to face and understand children directly. The handling of early childhood education at an institution (center base) cannot be separated from the handling of early childhood education at home (home base), the two are interrelated and compatible. Children's learning in institutions that can only fill $20 \%$ of children is put to the best possible use by the teacher. However, it does not mean that when the child is in the family environment, he / she does not receive proper education as is carried out in the institution. The method used in carrying out this service activity is in the form of inquiry-based learning by making home visits, greatly helping teachers and students in the teaching and learning process. The results obtained from the implementation of this community service are that children can still learn from home through teacher guidance by using Inquiry-Based Learning strategies

Keywords : children, the covid-19 pandemic, inquiry learning

\section{PENDAHULUAN}

Penanganan Pendidikan Anak Usia Dini pada lembaga (center base) tidak dapat dilepaskan dari penanganan PAUD di rumah (home base), keduanya saling terkait dan sejalan. Pembelajaran anak di lembaga dalam hal ini sekolah yang hanya dapat mengisi anak sebesar $20 \%$ dimanfaatkan sebaik-baiknya oleh guru. Namun tidak menjadi berarti apabila saat anak berada dalam lingkungan keluarga tidak mendapat pendidikan yang tepat seperti yang dilaksanakan pada lembaga.

Memasuki masa pandemi Covid-19 ini, pembelajaran dirasa sedikit terganggu. Orang tua dan guru dituntut untuk lebih kooperatif dalam melakukan pendampingan belajar terhadap anak. Fakta yang ditemukan di TKK St. Fransiskus Asisi Romba dan Kober Cahaya Baru, anak-anak menjadi tidak focus ketika dibiarkan belajar sendiri di masa Pandemi ini. Mereka cenderung lebih banyak bermain.

Bertolak dari masalah yang ditemukan di atas, maka guru wajib melakukan pendampingan belajar bagi anak di rumah selama masa pandemic ini. Guru harus memabngun komunikasi dengan orang tua, dan menyediakan metode-metode pembelajaran yang dirasa cukup efektif diterapkan dalam masa pandemic ini. Hal ini akan menjadi pembiasaan bagi anak. Ketika anak berada di rumah dan lingkungan, persentasi terbesarnya mencapai 80 persen, sedangkan ketika anak berada di sekolah/lembaga pendidikan persentasinya hanya $20 \%$ (Latif, dkk, 2013: 261). Ini berarti, anak pada dasarnya lebih banyak menghabiskan waktu bersama keluarga daripada di sekolah. Oleh karena itu, guru juga harus memberikan edukasi kepada orang tua mengenai metode pembelajaran, sebagai pengetahuan untuk mereka.

Salah satu metode yang cocok untuk pemblajaran di rumah pada masa pandemi covid-19 adalah dengan menggunakan strategi pembelajaran berbasis inkuiri.

Berdasarkan paparan kenyataan di atas, maka dilakukan kegiatan pengabdian pada masyarakat dengan judul "Program kegiatan pendampingan belajar anak di rumah pada masa pandemi covid-19 dengan menggunakan strategi pembelajaran berbasis inkuiri di Tkk St. Faransiskus Asisi Romba dan Kober cahaya baru usia 4 tahun" 


\section{METODE PELAKSANAAN}

Setelah dilakukan analisis terhadap akar penyebab suatu masalah seperti yang telah diuraikan di atas, maka metode yang digunakan dalam melaksanakan kegiatan pengabdian ini adalah berbentuk Pendampingan Belajar dengan menggunakan metode inkuiri untuk anak. Sasaran atau subyek untuk dilibatkan dalam program pengabdian ini adalah Anak usia 4 tahun di TKK St. Fransiskus Asisi Romba yang berjumlah 15 orang dan anak usia 4 tahun di Kober Cahaya Baru yang berjumlah 12 orang. Metode yang digunakan adalah metode observasi dan pendampingan. Kegiatana pendampingan ini dilakukan selama 1 bulan.

\section{HASIL DAN PEMBAHASAN}

\section{Hasil}

Kegiatan pendampingan yang dilakukan antara lain: di masa Pandemi Covid-19, anak diharuskan belajar dari rumah, kegiatan belajar dari rumah kurang terkontrol, anak belum bisa sepenuhnya belajar mandiri, jadwal belajar kurang terkontrol dan tersusun dengan baik, tes secara tertulis dan tes lisan dan tertulis untuk menguji sejauh mana pemahaman anak, orang tua masih belum sepenuhnya merespon ketika guru berkunjung ke rumah, serta guru belum memahami mengenai strategi pembelajaran inkuiri terbimbing. Selengkapmya deskripsi kegiatan disjaikan pada Tabel 1.

Tabel 1 Hasil Pendampingan Belajar

\begin{tabular}{|c|c|c|c|}
\hline \multirow{2}{*}{ No } & \multirow{2}{*}{$\begin{array}{c}\text { Nama } \\
\text { Kegiatan }\end{array}$} & \multicolumn{2}{|c|}{ Deskripsi Hasil } \\
\hline & & Sebelum kegiatan & Setelah kegiatan \\
\hline 1 & $\begin{array}{l}\text { Analisis } \\
\text { Kebutuhan }\end{array}$ & $\begin{array}{l}\text { 1. Di masa Pandemi Covid- } \\
\text { 19, anak diharuskan } \\
\text { belajar dari rumah } \\
\text { 2. Kegiatan belajar dari } \\
\text { rumah kurang terkontrol } \\
\text { 3. Anak belum bisa } \\
\text { sepenuhnya } \\
\text { mandiri }\end{array}$ & $\begin{array}{l}\text { Kegiatan ini merupakan pendampingan } \\
\text { belajar siswa di rumah untuk siswa TKK } \\
\text { ST, Fransiskus Asisi romba belum } \\
\text { melakukan proses pendampingan } \\
\text { belajar, mahasiswa terlebih dahulu } \\
\text { melakukan beberapa rangkaian } \\
\text { kegiatan persiapan, dengan rincian } \\
\text { sebagai berikut: } \\
\text { 1. Mahasiswa mendatangi pihak } \\
\text { sekolah (kepala sekolah dan guru } \\
\text { kelas) untuk menyampaikan maksud } \\
\text { dan tujuan pada tanggal } 05 \text { Agustus } \\
\text { 2020. } \\
\text { 2. Mendatangi orang tua siswa untuk } \\
\text { meminta ijin melaksanakan kegiatan } \\
\text { pendampingan tanggal 05 agustus } \\
\text { 2020. } \\
\text { 3endata materi yang sudah } \\
\text { diberikan oleh guru dan materi yang } \\
\text { harus dipelajari siswa secara mandiri } \\
\text { di rumah. }\end{array}$ \\
\hline 2 & $\begin{array}{l}\text { Jadwal } \\
\text { Belajar }\end{array}$ & $\begin{array}{lc}\text { Jadwal } & \text { belajar } \\
\text { terkontrol } & \text { dan }\end{array}$ & $\begin{array}{l}\text { 1. Menyusun jadwal pendampingan } \\
\text { belajar }\end{array}$ \\
\hline
\end{tabular}




\begin{tabular}{lcc}
\hline \multirow{2}{*}{ No $\quad$ Nama } & \multicolumn{1}{c}{ Deskripsi Hasil } \\
\cline { 2 - 3 } & Segiatan & \multicolumn{1}{c}{ Setelah kegiatan } \\
\hline & dengan baik & Jadwal pendampingan belajar ini \\
& & tidak teratur dan disesuaikan dengan \\
& & waktu luang mahasiswa dan juga \\
& & anak yang akan didampingi. \\
& 2. Menyusun materi pendampingan
\end{tabular}

a) Pendampingan pada siswa TK

B tema (Keselamatan di Rumah dan Perjalanan) sub tema Aturan Keselamatan di Jalan. Indikator : mendeskripsikan aturan-aturan keselamatan yang berlaku di jalan

b) Pendampingan pada TK $B$ tema (Daerah Tempat Tinggalku) sub tema Keunikan Tempat Tinggalku.

Indikator : mendeskripsikan ciri khas tempat tinggal.

\begin{tabular}{lll}
\hline 3 & Tes Awal & Tes secara tertulis
\end{tabular}

Tes awal dilakukan secara lisan dalam bentuk pertanyaan pengantar berkaitan dengan materi yang telah dipelajari siswa sebelumnya dan tentang pemahaman awal materi yang akan dipelajari.

\begin{tabular}{|c|c|c|}
\hline 4 & Tes Akhir & $\begin{array}{ll}\text { Tes lisan dan tertulis untuk } \\
\text { menguji sejauh } \\
\text { pemahaman anak }\end{array}$ \\
\hline \multirow[t]{2}{*}{5} & $\begin{array}{l}\text { Respon } \\
\text { Orang Tua } \\
\text { dan Guru }\end{array}$ & $\begin{array}{l}\text { 1. Orang tua masih belum } \\
\text { sepenuhnya merespon } \\
\text { ketika guru berkunjung ke } \\
\text { rumah. }\end{array}$ \\
\hline & & $\begin{array}{lr}\text { 2. Guru belum } & \text { memahami } \\
\text { mengenai } & \text { strategi } \\
\text { pembelajaran } & \text { Inkuiri } \\
\text { terbimbing. } & \end{array}$ \\
\hline
\end{tabular}

Tes akhir dilakukan dalam bentuk tes lisan dan tulis berkaitan dengan pemahaman dan penguasaan materi yang telah dipelajari bersama.

1. Respon orang tua

Secara garis besar orang tua sangat antusias dengan kegiatan pendampingan yang dilakukan oleh mahasiswa pada anak-anaknya. banyak hal yang menunjukan bentuk dukungan orang tua terhadap kegiatan ini diantaranya adalah mengingatkan anak mereka akan jadwal bimbingan dan juga mempersiapkan anak mereka untuk mengikuti bimbingan (kerapian berpakaian, perlengkapan tulis, dan ketepatan waktu).

2. Respon guru

Kepala sekolah maupun para guru TKK ASISI ROMBA sangat mendukung dan mengapresiasi kegiatan bimbingan belajar yang dilakukan oleh mahasiswa pada beberapa siswa TKK ASISI ROMBA. Bentuk dukungan dan apresiasi yang dilakukan adalah dengan mengijinkan mahasiswa melakukan bimbingan belajar dan juga terlibat aktif dalam memberikan data materi-materi yang telah siswa pelajari di sekolah dan materi-materi yang belum dipelajari siswa dan harus dipelajari 


\begin{tabular}{ccc}
\hline \multirow{2}{*}{ No Nama } & Deskripsi Hasil \\
\cline { 2 - 3 } & Segelelah kegiatan kegiatan & \multicolumn{1}{c}{ Setelan } \\
\hline & siswa secara mandiri di rumah. \\
& Dukungan juga diberikan guru \\
& terhadap mahasiswa dalam bentuk \\
& masukan dan ide-ide berkaitan \\
& dengan cara atau teknik yang dapat \\
digunakan dalam proses \\
bimbingan.
\end{tabular}

Kegiatan pendampingan belajar dapat dilihat pada Gambar 1 berikut.

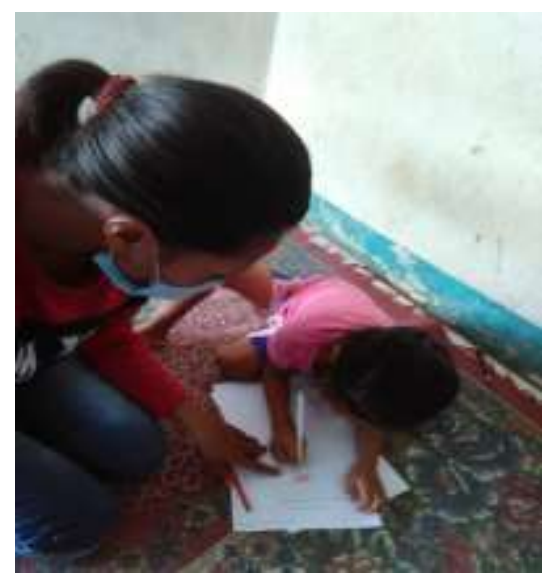

\section{Gambar 1. Guru memberikan bimbingan tertulis}

\section{Pembahasan}

Pembelajaran berbasis inkuiri dengan mealakukan kunjungan rumah, sangat membantu guru dan murid dalam proses belajar mengajar. Dengan strategi pembelajaran ini tim pendamping melakukan kunjungan rumah untuk peserta didik yang berusia 4 tahun, dengan mengambil tema TANAH AIRKU.Pada tema ini tim pendamping selaku pendidik Paud memberikan tugas kepada anak didik tim pendamping yaitu menebalkan kata pada huruf bendera dan mewarnai gambar bendera.

Adapun alat dan bahan yang tim pendamping persiapkan untuk melakukan kunjungan rumah, antara lain LKS, dan kerayon. Hal ini untuk memudahkan anak didik dalam melakukan tugas rumah, dan waktu yang tim pendamping temouh untuk melakukan kunjungan rumah adalah satu hari untuk 5 anak.

Selama mengikuti kegiatan bimbingan belajar siswa di rumah banyak hal baru yang didapatkan oleh mahasiswa. Banyak hal yang cukup mudah dipelajari secara teori namun sulit untuk diterapkan secara langsung. Banyak pelajaran bermakna yang didapat 
diantaranya adalah bagaimana seorang guru harus mampu memahami berbagai karakteristik peserta didik dan memahami kondisi dan kebutuhan peserta didik.

\section{KESIMPULAN}

Melalui kegiatan pendampingan belajar di rumah dengan menggunakan strategi pembelajaran Inkuiri, terbimbing anak-anak dapat belajar dengan mudah dan tetap dalam pengawasan guru. Pandemi Covid-19 tidak menjadi halangan bagi anak untuk tertinggal materi.

\section{DAFTAR PUSTAKA}

Anam, K., (2016), Pembelajaran berbasis inkuiri, Pustaka pelajar, Yogyakarta

Camenzulia, J. (2014). "Using inquiry-based learning to support the mathematical learning of students with SEBD". International Journal of Emotional Education. 6 (2), 69-85.

Darma, W. et.al. (2014). "Studi komparatif model pembelajaran inkuiri bebas dan generatif terhadap pemahaman konsep dan kreativitas siswa". e-Journal Program Pascasarjana Universitas pendidikan Ganesha program Studi IPA. 4 (1), 1-10.

Dewi, N.L., dkk, (2013), Pengaruh pembelajaran inkuiri terbimbing terhadap sikap ilmiah dan hasil belajar IPA. e-journal program Pascasarjana Universitas Pendidikan Ganesha, Volume 3 Tahun 2013.

Latif, Mukthar, Zukhairina, Zubaidah, R., \& Afandi, M. (2013). Orientasi baru pendidikan anak usia ini: teori dan aplikasi. Jakarta: Kencana.

Mursid. (2016). Pengembangan pembelajaran paud. PT remaja rosdakarya. Bandung.

Puspasari, A. (2007). Mengukur konsep diri anak. Jakarta: Gramedia.

Sanjaya, W. (2013). Strategi pembelajaran berorientasi standar proses pendidikan. Jakarta: Kencana Prenada Media Group.

Wibowo, T.W., (2016), Penerapan model inkuiri terbimbing dalam meningkatkan efikasi diri dan penguasaan konsep siswa pada materi larutan elektrolit dan non elektrolit. Skripsi. FMIPA UNILA, Bandar Lampung. 